\title{
Reconsideration of Local Government at Village Level: A Legal Study
}

Nusrat Hasina ${ }^{*}$, Gazi Saiful Hasan ${ }^{2}$

${ }^{1}$ Senior Lecturer, Department of Law, Leading University, Sylhet-3100, BANGLADESH

${ }^{2}$ Assistant Professor, Department of Law and Justice, Metropolitan University, Sylhet-3100, BANGLADESH

*Corresponding Contact:

Email: shampanusrat@yahoo.com

Cell Phone: +8801717134094

\begin{abstract}
Establishing a local government institution in appropriate tire can easily help to get the utmost benefit of decentralization in Bangladesh. In this paper, village has been identified as an important tier to fulfill the objectives. Analysis of the historical development of local government in Bangladesh has been taken into concern to prove the fact. This paper especially focuses as well recommends establishing local government at village level which is the lowest tier of administrative decentralization in Bangladesh. Village government can also be the best tier to practice local level democracy and can ensure effective participation in decision making and also in implementing other activities related to villagers.
\end{abstract}

Keywords: Local Government, Constitution, Rural Development, People's participation, Village, Bangladesh

\section{INTRODUCTION}

The lowest tier of administrative decentralization in Bangladesh is village. The establishment of local government at village level has always been an issue in different time. From the evaluation of historical development of local government at village level, it is observed that all government, democratic or martial law, tried to establish the same but always failed to persist due to various reasons. The main reason can be identified as the ignorance of concerned constitutional provisions and the principles of establishing a tier of local government in Bangladesh. If the main objectives of local government are to provide the services of central government to the grass root people and ensure effective public participation in the same level, it can easily be possible by an efficient tier of local government at village level. Presently, the lowest tier of local government is established at Union level in Bangladesh. Although, Union is comprised of some villages; the Government should have considered the historical evaluation of village government and taken initiatives towards an active institution in the same. 


\section{OBJectives OF THE Study}

The main concern of this research study is to find out the importance of having a tier of local government at rural in Bangladesh. Other objectives are to show a way of establishing the same, analyse the steps taken by all government since the independence as well as the existing scenario. This paper also examines the reasons behind the failure of all previous local government of village level.

\section{Methodology}

To find out the goals of the study, historical approaches of research method has been resorted to. Historical development and critical evaluation about the topic have been taken into consideration to compare with existing situation in this regard. Depending upon the nature of the research study to develop the same, all information has been collected from Books, Journals, Case Laws, Newspapers, and Websites.

\section{MeANing OF THE TERM 'LOcal Governiment'}

Local government is a form of decentralization of central government. Local government is an integral part of body politic of a country, recognized or created under law for the management of local affairs of a human settlement with geographic boundaries. It can be stated that local government means an institution which is constituted of elected people and which also ensures effective public participation in case of all types of activities related to them. According to United Nations, the term local self-government refers to a political subdivision of a nation or state which is constituted by law and has substantial control of local affairs, including the power to impose taxes or exact labour for prescribed purposes (Siddiqui, 2005). Local government also means 'self-government' that connotes an idea of liberty and autonomy indicating entire decision making authority to the governing unit. It has already got attraction in the world as a better way for practicing democracy as well as for ensuring good governance in grass root level. Local government is defined as "the totality of processes (or functions) which contribute to the development of a specific area as well as the norms necessary for mediating a harmonious integration of actions". Basically, it can also ensure equal services provided by the central government to the all level of the society.

Local government should, nevertheless, be valued in a democracy more ardently than the numerous other bodies that also shape aspects of urban and rural life (Talukdar, 2009). In Kudrat-E-Elahi Panir vs. Bangladesh, the court says about the meaning of local government that "...it is meant for management of local affairs by locally elected persons. If Government's officers or their henchmen are brought to run the local bodies, there is no sense in retaining them as Local Government Bodies." By observing all the definition of local government, it can be said that precedent and other definitions describe the actual meaning of local government. So, the characteristics of local government can be summarized as it should be an elected body for working in a limited territory ensuring public participation and the main function of that will be the regional development in every aspect of life.

\section{Historical BACKGROUND OF LG AT VILLAGE LEVEL}

The idea of village government in the India sub-continent is ancient. And since then depending upon this system, local government has got an institutional shape and constitutional recognition in different countries. The way to develop the condition of life of local people and being the part of state laws has gradually got a strong institutional structure. Though, there is now a vast structural variation in local government system, it is ultimately the outcome of traditional continuity of small institution structured in village 
level. To make it adoptable, the historical basis of local government and its five stages of division must be considered (Talukdar):

- $\quad$ Buddhist and Hindu Ruling Period (2300 Years dated back)

- Muslim Ruling Period (1206-1765)

- $\quad$ British India Ruling Period (1757-1974)

- Pakistan Period (1947-1971)

- $\quad$ Bangladesh Period (1971-till date)

\section{Buddhist and Hindu Ruling Period:}

It is really hard to identify the antiquity of institutions at village level. But, it is assumed that village government existed in Vedas period. The existence of village self-government has also been identified in Quatilaya's Arthashastro, a very ancient book (Hasan, 2000). Such indicate how old the various village institutions are. In every village, there were local institutions in different names as Gramin, Gramika, Grampala, Panchayet, Majlish, Shabha, and Sommittee etc (Banglapedia). Inspite of lacking of any legal status those various institutions of villages were respected and obeyed by all villagers. By evaluating the history, the existence of Headman (pradhan) in village was also traced out who was generally nominated from the powerful families of the village. He was also responsible to contact the central authority by collecting tax. In the above mentioned time there were structural differences in headmen and panchayet system. The area of Bengal now named as Bangladesh was comprised of the regions of eastern part of Indian sub-continent. The then village administration of Bengal was conducted by headmen. The post of headman was generally hereditary.

\section{Muslim Ruling Period (1206-1765):}

Muslim rulers started to rule the Bengal by defeating the ruler of senas. At that time procedure of conducting village administration was as same as the ancient period except for some minor changes. But, the traditional continuity of ancient village administration system steadily declined due to commencement of British ruling.

\section{British India Ruling Period (1765-1947):}

The main reason behind the abolishment of traditional village administration was the power of collecting revenue by British in result of defeating the last independent Nawab of Bengal at palashi battle. Finally, institutions based on villages were weak for a new Zamindari system introduced by permanent settlement in 1793. The British government tried to establish local level institution in various ways to control the local area but failed to do that. As a result it had been tough for central authority to retain a good relation with local people. In the mean time the British government was worried for rebel of sipahi which occurred in 1987 and introduced a law titled 'Village Chaowkidary Act, 1870' to improve the situation of villages and to enhance the relation between central government and local people (Mallick). By this act the traditional panchayet system was reintroduced. The above mentioned law gave district magistrate the power to make panchayet by appointing 3-5 villagers. Village panchayet could exercise the power to appoint chowkidar to whom the power of maintaining law and order situation, and various functions directed by panchayet were vested. Another function of chowkidar was to inform about crimes to the nearest police stations. But, by this act it was hardly possible to make rural development and remove the harshness. Considering the situation the British government started to investigate the facts behind this. To solve the problem different commissions proposed to establish local institutions. Lord Ripon's resolution, 1882 played a vital role in this respect. By this resolution a structure of the development activities for grass root people as well as effective participation of them in their own activities were ensured. To promote local government 
institution government enacted Bengal Local Self Government Act, 1885. The act created three tiers local government such as Zilla Board in District, Local Board in Sub-division, and Union Committee in Union level. Union committee was comprised of some villages. But, any direct local institution at village level such as panchayet was abolished by the act. Later on Bengal Village Self Government Act was promulgated in 1919 (Rahman, 2005). This act abolished Union Committee and replaced the Union Board. The functions of Union Board were different development activities including maintaining the law and order situation. In British regime both election and nomination procedure to comprise of the local government were practiced.

\section{Pakistan Ruling Period (1947-1971):}

In 1947 sub-continent faced a change in geographical politics. India and Pakistan were born as two independent states. Pakistan comprised of two parts i.e. East Pakistan and West Pakistan. The then East Pakistan is now the independent Bangladesh. After emerging as an independent state no steps were taken reckoning local government institution. To get the changes it had to wait until 1957. In that year some important changes took place. Establishment of local government through election was one of them. In 1958 military government took the power and in 1959 the government gave a structural design of local government by Basic Democracy Order. Under that order local government in rural area was divided into four tiers (Mallick). Union Council was the lowest tier centering the village where nomination and election were allowed to comprise of the council. In 1962 provision of nomination was abolished and the idea of representative government was established.

From the evaluation of local government institutions dated from time immemorial to independence of Bangladesh it can clearly be stated that sometimes local institutions in single village were present, sometimes that were abolished depending upon the wish of rulers. In ancient period villagers established village administration for their own necessities but gradually it had been patronized as an organ of central government to provide service to the grass root people to keep stable and existence of itself.

\section{Bangladesh Ruling Period (1971-till date):}

Bangladesh gained its independence in 1971 in respect of nine month bloody war. By this it had been sketched out in the world's map as an independent state. After the emergence of Bangladesh as a new state, various steps were taken relating to local government. Though, that was limited to the abolishment of all Parishad and changing the name of the tier only.

Sheikh Mujibur Rahman's Regime (1972-1975): The then President, Sheikh Mujibur Rahman, abolished all Parishads of local government except division were abolished by promulgating an order, no 7, in 1972. Village centered local government union council was renamed as Union Panchayet and the power of controlling the panchayet was vested to the Circle officer (development) (Khan, 2009). This scenario was the same until the promulgation of a new Order of 22 by the President. That Order made great changes to history of local government at union level. The objective of the Order was to make a tier of elected representative government. In 1975 Bangabandhu Sheikh Mujibur Rahman declared a new political administrative structure. Establishing Presidential form government, Bangabandhu planned to create institution based on villages. The plan to fulfill the objectives of the system to make village as the economic and administrative focal point, five years plan by making village co-operatives comprising of 500-1000 family in a villages were prepared (Mallick). The central government would provide all services through the village co-operatives. Public participation would also be ensured by the process. The central authority tried to make a close relation with grass root people but dream was turned into failure because of the assassination of Bangabandhu Sheikh 
Mujibur Rahman with most of his family members.

Ziaur Rahman's Regime (1975-1980): Towards the climax of the tenure of the architect of independence, Bangabandhu Sheikh Mujibur Rahman, undemocratic military government took the power of state and the chief of the then army, Ziaur Rahman, acted as head. Though, the way of taking power of government was not democratic, to uphold own leadership and personality as well as to make a relation with root people Ziaur Rahman realized the necessity of having local government at local level. To fulfill his dream three tiers of local government were made by an ordinance promulgated in 1976. But later on in 1980 with an amendment of above said ordinance 'Swanirvar Gram Sarkar' system was established which was comprised of with a head, twelve members in which two were women (Ali, 2015). Various steps to ensure people's participation and make rural economics strong taken by Ziaur Rahman made him much reputed. But Swanirvar Gram Sarkar had also failed to be the effective one because of the assassination of the President Ziaur Rahman and finally the system established by him was abolished by a martial law order promulgated in 1882 by General H.M. Ershad, the then Chief of Army.

Ershad's Regime (1982-1990): Although, H.M. Ershad abolished lowest tier of local government institution, he brought major changes in his tenure regarding the improvement of local government. In his time structural and legal changes for the same have taken place. No step was taken relating to establishment of a tier in the village until 1989. But the main motto of Ershad was depending upon development of rural arenas. As a result he got reputed as 'Village friend'. He promulgated Palli Parishad Act in 1989 which would be comprised of an elected chairman and eight members including two women members. As it was made in the marginal time of his regime, Palli Parishad Act did not come in effective.

Khaleda Zia's Regime (1991-1996): Bangladesh faced another change in its governmental form in 1991. Democratic form of government was reestablished by the twelve amendments of the constitution. Begum Khaleda Zia along with her political party, Bangladesh National Party, formed the government by popular vote. Her government made Local Government Structure Review Commission to reshape it. That commission proposed to establish 'Gram Shava' in village level which would be comprised of ten members including two women, two farmers, two farming laborer. But the recommendation did not come into existence. As a result Union was the lowest tier established by that government from 1991 to 1996.

Sheikh Hasina's Regime (1996-2001): Awami league got the power of the government in 1996 by the 7th election of Parliament. Firstly, the government made a commission to reorganize the local government tiers in Bangladesh. The commission proposed a tier to be established at village level beside other tiers of local government (Rahman). According to the proposal of the commission, the government enacted Gram Parishad Act, 1997 (Hasan). Under that act village government would be established based on ward. The elected Chairman of Union Parishad would be ex-officio chairman of the Gram Parishad. Gram Parishad would be consisted of three members including two women members. Government officials were also given the opportunity to be the member of the Parishad. Though the act for establishing gram Parishad was made, no step was taken to constitute the same.

Khaleda Zia's Regime (2001-2006): For the second time Khaleda Zia took the charge of the government in 2001. During that tenure the government abolished the Gram Parishad Act, 1997 and enacted a new law titled Gram Sarkar Ain, 2003 for establishing Gram Sarkar in village based on ward as like as the previous government. Though the 
preamble of the said act reflected a local institution of representative nature to ensure people's participation in development activities but it also contained the provisions of the nomination rather than election in the presence to constitute the gram sarkar.

Sheikh Hasina's Regime (2009 to till date): Though after taking the charge of government many laws regarding local government have been passed during this tenure such as Local Government (City Corporation) Act, 2009, Local Government (Municipal Corporation) Act, 2009, Union Parishad Act, 2009 (Ministry of Local Government Division, Bangladesh). Upazila Parishad Act, 1998 has also been restored. But no step has yet been taken to establish a village government.

\section{Constitutional Basis AND VilLage Government}

Provisions of the Constitution of Bangladesh regarding local government have made the constitution unique. It is hardly stated in the Constitution of any other country about Provisions regarding local government such as Bangladesh. Moreover, provisions relating to local government were added at the time of commencement of the Constitution which indicated the commitment of developing the country. Article 59 and 60 of the Constitution of the People's Republic of Bangladesh are related to local government which recognizes local institutions as a second fiddle of central government. Local government institutions will be constituted through elected person whose functions will also be determined by the Act of Parliament. Moreover, according to the Constitution the functions include (Article60, The Constitution of People's Republic of Bangladesh): (a) Administration and the work of public officers; (b) the maintenance of public order; (c) the preparation and implementation of plans relating to public services and economic development. The duties of governing local people will be vested in an administrative area. Administrative area means district or any other area designated by law to fulfill the objectives of article 59 of the Constitution. So, it is clear that an area must be designated by law as an administrative unit before vesting the duties upon its elected representatives. Considering the above facts the government may establish a tier of local government at village level. But ignorance of these provisions will not be allowed in this regard because constitutional law is the supreme law and other laws inconsistent shall be void. Article 11 of the constitution refers to ensuring the establishment of local government in every administrative unit. But it bears importance to some extent for being placed in the chapter of fundamental principles of state policy of the constitution. Besides, the aforesaid provisions article 16 describe various policies regarding the elimination of inequality of urban and rural condition life by establishing small industries and agricultural revolution. Education, communication, and public health should also be improved to bring a great change for rural areas. The state will also take steps to give equal opportunities and to attain an equal stage of economical development in every sphere of republic. The state is not obliged to perform the same as the implementation of above policies is related to the social and economical condition of the state. But to fulfill the objectives of article 59 and 60 of the constitution of Bangladesh, the establishment of local government at village level by designating it as an administrative area can be successful way in this regard.

\section{Reasons Behind the failure of Establishing Local Governiment at VILLAGE LEVEL}

Since the independence to till date initiatives taken by all government to establish local government centering village have failed due to various reason. The failure has occurred sometimes for the reason of politics and weakness of making laws regarding this. A 
common practice in Bangladesh is to abolish the steps taken by the previous government which is an obstacle to make sustainable development in any respect. Structural and legal weakness in establishing village government Acts as a factor not to make it stable and effective. Many times different personnel as martial law administrator have the power to take the charge of government in absence of democratic government. Observing the historical background of local government all governments get inspired to make a government based on village to ensure public participation but in every step the desire was to fulfill political person than to establish an effective and representative local government tier. The government always tries to establish it ignoring the Constitutional philosophy of local government. The mail principle of local government under the constitution is the establishment of it in every administrative stage through election. Articles 9 (now abolished), 11, 59, 60 referred in the constitution relating to local government were suspended in 1975 and those were re-stored in 1991. The supreme law of our country, constitutional law, had been ignored but government took initiatives to establish it. Moreover, every government considering the importance of local government tried a lot to establish local government at village. For the lack of ensuring public participation in development in works and making a strong structural design and other steps were not effective. People cannot expect any benefit from such practice. Despite of making many laws, consuming times and bearing a lot of expenditure, it has yet not been established a strong and effective local government at village level.

The last Act relating to village government titled Gram Sarkar Ain, 2003 was declared as unconstitutional and void by the Supreme Court. For this it can easily be understood about the factors for the failure of the said government. The Supreme Court gave the verdict on the basis of constitutional provisions regarding local government. Some important matters were taken into consideration for giving the judgment. Those are as follows (BLAST vs Bangladesh):

- Whether village is an administrative unit under the provision of the constitution of Bangladesh. The Supreme Court found contradictory provision in section 3(4) of Gram Sarkar Ain, 2003 in this regard.

- Though the said Act recognized the repetitiveness of people, to make it effective no provision was included in the Act. Moreover, the wish of controlling gram sarkar thorough the nomination procedure by central government was clearly visible.

- The court also questioned about the right of enacting any law of the parliament. Though they are entitled to enact any type of law, that should be according to the constitutional mandate. As a result the Court shouted it as a colorable legislation.

\section{Recommendations for Establishing a Model Village Government}

To establish a model village government legal factors and composition of village government for conducting its functions effectively should be taken into consideration. Two leading cases, Kudrat E Elahi Panir vs Bangladesh 44 DLR (AD) (319) 1992 and BLAST vs Bangladesh and Others 60 DLR (208) 234 can be the pioneer to take the initiatives regarding this. These two judgments should be followed as the guidelines to establish the same. Besides, other factors affecting the villagers should also be taken into consideration. Firstly, the village should be declared as an administrative unit under the provision of the Constitution of Bangladesh (The Constitution of People's Republic of Bangladesh, op cit, Article 152.2). To compose of the village government people's participation should be ensured through direct election. The nomination process will be strictly avoided to constitute the Parishad. Women's effective participation is needed to take into consideration to be a pioneer institution for empowering themselves. Considering the mentioned factors government may take steps for enacting a law to establish village government. The act should also include the provisions regarding territory, composition, 
time of election, qualification, and disqualification to be a member of the Parishad, functions of the Parishad, procedure of making budget and sources of income. The existing as well as lowest tier of local government at village level, union Parsishad, is constituted of nine wards. So, the territory of village government may be based upon a ward. Each ward will have an elected village government. Government should be more conscious to vest the functions upon village government. Because the main reason for establishing village government is the development of villages by ensuring people's participation. Nowadays many elements of the modern civilization are in out range of their touch. So, by ensuring effective participation steps should be taken to develop rural economy and social condition. By this it will be possible to give a minimum solution regarding fundamental problems of rural life. So, firstly the basic problem of village life is to be identified and bars of their development, it will then be easy to take proper initiatives regarding the same. The following functions can be vested to the village government:

- The duties of educational development especially primary education and program for the aged person should be vested to the village government.

- Though agriculture is the main profession of the villagers, lack of technological support, sufficient elements of agriculture, and because of not aware of a modern way of cultivation farmers can not develop in this sector. Village government can provide seeds, fertilizer, irrigation and other facilities on time to the concerned people.

- The scenario of the health condition of the villageers is yet not fabulous. Village government can play a vital role to develop primary health by stopping all types of misinterpretation. To provide the basic health service to the grass root people hospital, dispensary should be established and maintained by the village government.

- To develop and maintain the roads of villages the government can take the step. Besides, they should concentrate to establish rural hats and bazaars for running a stable rural economy.

- People of the village can participate in implementing and various grant providing program by village government. This government will update the birth and death statistics by birth and death registration program in this regard.

- Village government should also take proper steps to retain local customs, culture and they will patronize these local phenomenons in fulfilling the objectives.

- Village government will take the step with the help of the other authority for stopping child marriage, dower, and such type of other social aggression.

- Effective initiatives should also be taken to provide drinking water and introduce as well as inspire to use alternative sources of fires. Besides to improve the condition of environment and reserve forest people should be made conscious.

- To maintain law and order situation of the villages, maintenance of village policing system should be vested to the village government.

Most of the recommended functions of the village government have already been included in the act of Union Parishad of 2009. If village government is established, the above mentioned function should be transferred to the village government. Because when the problems are created from the grass root levels, the priority should also be given to that place. As the territory of village government will not be large, the functions vested upon the government can perform such effectively. Village government will make a way to develop in education, health, agricultural sector. In this way all villages may be developed in economic and social perspective. According to the article 60 of the Constitution of Bangladesh the act for establishing village government will also include provisions relating to budget making, sources of income. Land tax, land transfer tax, registration fee of nongovernment school, hospital, dispensary, the fee of leasing hat, bazaar etc. income from the property of village government may be the sources of income. Other provisions for 
conducting village government may be according to as some other laws for local government avoiding all contradictory provisions with the Constitution.

\section{CONCLUSION}

There is no way but to establish local government at village level to ensure practicing democracy in grassroots level. Historical development of local government in this area also suggests the same in this regard. So, necessary steps should also be taken to fulfill the constitutional objectives maintaining the constitutional obligation. In this way it is possible to develop the social and economic condition of rural people. It will not only enhance better communication and better life but will also strike an adroit balance between the law and society of the village. Law must not only be seen but also be applied to ensure justice to attain transparency and order such must be granted.

\section{REFERENCES}

Ali, Shawkat. 'Gram Sarkar: Experiments for Participatory Government at Grassroots'. Retrieved from http://www.asiaticsociety.org.bd/journals/Golden_jubilee_vol/articles/H_448\%20(AMM\%20Sh awkat).htm , Accessed on $20^{\text {th }}$ January, 2015

Article-60, The Constitution of People's Republic of Bangladesh. (1972), Retrieved from: http:/ /bdlaws.minlaw.gov.bd/pdf_part.php?id=367, Accessed on 20th February, 2015

Banglapedia. National Encyclopedia of Bangladesh. Retrieved from: http:// www.banglapedia.org/httpdocs/HT/L_0122.HTM, Accessed on $20^{\text {th }}$ January, 2015

BLAST vs Bangladesh. Cited in 60 DLR (2008) 234.

Hasan, S. (2000) The Chittagong University Journal of Law. Vol. V. (p. 123-145)

Hasan, S. op cit.

Kudrat E Elahi Panir vs Bangladesh, 44 DLR AD 1992319.

M. Maksudur Rahman. Bangladesher Sthanio Sayotto Shashon, Aligarh Library, $4^{\text {th }}$ Ed. Pp- 52,82, 2005

M. Maksudur Rahman., op cit, p-78

M. Mohabbat Khan, Decentralization of Bangladesh: Myth or Reality, ISBN: 984-70019-0039-4, A H Development Publishing House, First Edition, pp-70, 2009.

Mallick, B, op cit, p-32.

Mallick, B, op cit, P-40

Mallick, B. op cit.

Ministry of Local Government Division, Bangladesh. Retrieved from: http://www.lgd.gov.bd/, Accessed on $25^{\text {th }}$ February, 2015

Siddiqui, K. (2005). Local Government in Bangladesh. Evaluation of Local Government in Bangladesh. p. 40. Dhaka. The University Press Limited.

Talukdar, R.I. (2009) Rural Local government in Bangladesh. Legacy and History (p-25) Dhaka: Osder Publications.

Talukdar, R.I., op cit, $p$-25

The Constitution of People's Republic of Bangladesh, op cit, Article 152(2).

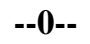

